\title{
CHARACTERIZATION OF Cochliobolus sativus AND Pyrenophora teres FUNGI BELONGING TO THE LEAF SPOT COMPLEX OF BARLEY (Hordeum vulgare) ISOLATED FROM BARLEY SEEDS IN MEXICO
}

\author{
Teresa Romero-Cortes ${ }^{1 a}$, Ernesto Alejandro Zavala-González ${ }^{2}$, Victor Hugo Pérez España ${ }^{1 \mathrm{~b}}$, José \\ Esteban Aparicio-Burgos ${ }^{1 \mathrm{c}}$, and Jaime Alioscha Cuervo-Parra ${ }^{1 \mathrm{~d} *}$
}

${ }^{1 a}$ Escuela Superior de Apan, Universidad Autónoma del Estado de Hidalgo, Carretera ApanCalpulalpan, Km 8, Chimalpa Tlalayote s/n, Colonia Chimalpa, Apan, Hidalgo. Mexico

ORCID: https://orcid.org/0000-0002-2615-1435

${ }^{1 b}$ Escuela Superior de Apan, Universidad Autónoma del Estado de Hidalgo, Carretera ApanCalpulalpan, Km 8, Chimalpa Tlalayote s/n, Colonia Chimalpa, Apan, Hidalgo. Mexico

ORCID: https://orcid.org/0000-0003-2519-8677

${ }^{1 c}$ Escuela Superior de Apan, Universidad Autónoma del Estado de Hidalgo, Carretera ApanCalpulalpan, Km 8, Chimalpa Tlalayote s/n, Colonia Chimalpa, Apan, Hidalgo. Mexico

ORCID: https://orcid.org/0000-0002-7611-7825

${ }^{1 d}$ Escuela Superior de Apan, Universidad Autónoma del Estado de Hidalgo, Carretera ApanCalpulalpan, Km 8, Chimalpa Tlalayote s/n, Colonia Chimalpa, Apan, Hidalgo. Mexico

ORCID: https://orcid.org/0000-0002-6586-8914

2 Departamento de I + D + i, Atlántica Agrícola S. A., Corredera 33, Villena, Alicante, Spain

ORCID: https://orcid.org/0000-0001-8567-1409

* Corresponding author E-mail: jalioscha@gmail.com

\section{ABSTRACT}

Barley (Hordeum vulgare) is generally used for animal feed, and food and beer production industries. Its production is affected by phytopathogens, of which Ramularia collo-cygni, Puccinia spp., Pyrenophora teres and Cochliobolus sativus are of global concern. In Mexico, there are few studies available on the morphological and molecular identification of fungi responsible for causing fungal diseases of barley. Therefore, the objective of this work was to identify, morphologically and molecularly, fungi isolated from barley seeds. The strains were identified by morphological analysis and by sequencing of the conserved ITS1/5.8s/ITS2 region of the ribosomal gene. Morphologically, the strains were identified as $P$. teres and $C$. sativus, which was confirmed with bioinformatics techniques using BLAST and MEGA6 programs. The results showed that the strains isolated from barley seeds in the highlands of Mexico were consistent with the sequences of $P$. teres and $C$. sativus deposited in the GenBank. These results will allow identifying some of the species of native fungi found in barley seeds.

Key words: Cochliobolus sativus, Hordeum vulgare, ITS, Net blotch, Pyrenophora teres. 


\section{INTRODUCTION}

Barley (Hordeum vulgare) is the fourth most cultivated cereal worldwide, after corn (Zea mays ssp. mays), common wheat (Triticum aestivum), and rice (Oryza sativa) (FAO, 2020; Producción Agrícola Mundial, 2020). Climate change has led to the implementation of new cultivation practices, which has resulted in changes in the profiles and ranges of pathogens that affect these crops (Pautasso et al., 2012). Barley plants are affected by the presence of several types of foliar pathogenic fungi, such as Ramularia collo-cygni, Pyrenophora teres, Cochliobolus sativus, Puccinia hordei and Rhynchosporium secalis, which are responsible for causing diseases (Carretero et al., 2015; Romero et al., 2020). In fact, net blotch (NB) caused by $P$. teres (anamorph Drechslera teres) can induce yield losses greater than $50 \%$ in barley (Statkeviciute et al., 2010; McLean and Hollaway, 2018) due to a reduction in the number of kernels per spike, grain size, and total photosynthetic leaf area (Dumalasová et al., 2012). In template regions, high rainfall (between 153 and $154 \mathrm{~mm}$ ) aggravates the damage caused by NB (Steffenson and Webster, 1992; Wu et al., 2020). However, epidemics have also occurred in areas with lower rainfall (Steffenson and Webster, 1992; Ellwood et al., 2018), where barley seeds with a high fungal load constitute an inoculum for $P$. teres survival from one season to another, becoming a very efficient way of transmitting the pathogen to the seedling, coleoptile and roots (Couretot et al., 2017). NB has two forms differentiated by the symptoms: net form (NFNB) and spot form (SFNB). NFNB, caused by $P$. teres f. teres, induces horizontal and vertical crisscrossed dark brown venation on barley leaves that can become chlorotic (Dumalasová et al., 2012), whereas SFNB, caused by $P$. teres $\mathrm{f}$. maculata, produces circular or elliptical dark brown spots surrounded by chlorotic leaf tissue (Carlsen et al., 2017).

The pathogen agent of NFNB can be easily identified in barley plants based on symptomatology. However, SFNB presents non-cross-linked symptoms without a netspot (Marshall et al., 2015), which closely resemble those caused by C. sativus (Rehman et al., 2020). When spikes are attacked by any of these fungi, the infected seeds become of a dark color (Carmona and Sautua, 2015). Therefore, macroscopic characteristics observed in barley seeds are not useful for the identification of the fungus responsible for the infection (Carmona and Sautua, 2015) because there are several fungi that can cause discoloration and seed darkening, such as Alternaria spp., Drechslera verticillata, D. campanulata, and Bipolaris zeicola (Medd et al., 2003; Manamgoda et al., 2014; Romero-Cortes et al., 2019). Consequently, microscopic observations of the conidia are required to distinguish the pathogen agent of SFNB (Poudel et al., 2019), and also to differentiate between $C$. sativus and $P$. teres net-spot blotch-causing fungi since they present no macroscopic morphological differences (Statkeviciute et al., 2010).

The genus Cochliobolus is another group of fungi that affects barley, including C. sativus (Sivanesan, 1990), (anamorph Bipolaris sorokiniana, syn. Helminthosporium sativum), which presents a wide range of hosts in the Poaceae family (Musaed et al., 2013). C. sativus is widely distributed (Bashyal et al., 2011) and constitutes a continuous genetic group of isolates that vary in virulence and aggressiveness against several cereals and grasses (Duveiller and Altamirano, 2000). Affected crops include barley, spring wheat, rye, weeds, and other grass species (Jones et al., 1983; Wu et al., 2020). Of these cereal species, wheat and barley are the most highly produced crops (Murray et al., 2009; Mata-Santoyo et al., 2018). In barley, C. sativus causes different diseases such as black point, common root rot, and spot blotch, which can affect both plants and/or seeds (Kumar et al., 2002; Manamgoda et al., 2014; Romero et al., 2020; AlSadi, 2021). Severity of attack and damage caused to the crop is greater in soils with poor fertility, and high temperature and humidity conditions (Duveiller and Altamirano, 2000; Savary et al., 2011; Kumar et al., 2020).

Two different pathological stages can be distinguished: the interference of the photosynthesis process, followed by the interference in the absorption of nutrients and water by the roots (Forcelini, 1991; Carmona and Sautua, 2015; Carmona and Sautua, 2017). Affected plants result in fewer tillers and grains per spike, as well as reduced seed germination, plant growth, and yield. In particular, yield reduction by $C$. satious can reach up to $30 \%$ (Kumar et al., 2002; Ghazvini and Tekauz, 2007; Al-Sadi and Deadman, 2010; Sultana et al., 2018).

The damage caused by the members of the Pleosporaceae family in barley results in severe economic losses worldwide. In this sense, some farmers are unable to use technology and rely on family labor. In the highlands of Mexico, a recent study focused on the morphological identification of fungi belonging to the leaf spot complex in barley (Romero et al., 2020). However, there is a need for the molecular identification of the pathogenic fungi associated with this crop in the area. Therefore, the aim of this research was to determine, morphologically and molecularly, strains of pathogenic fungi isolated from barley infected seeds in the highlands of Mexico, in the states of Hidalgo, Puebla and Guanajuato. 


\section{MATERIALS AND METHODS}

\section{Fungal strain isolation}

Fungal strains were isolated from five varieties of barley seeds with dark color symptoms collected during the years 2008 to 2014 in the highlands of Mexico. Fungi were isolated in Petri dishes, containing 20 seeds previously disinfected by immersion in a $2 \%$ solution of aqueous sodium hypochlorite for $120 \mathrm{~s}$, followed by three washes with sterile water. Afterwards, the seeds were placed in moist chambers and incubated at $15^{\circ} \mathrm{C}$ under visible light to induce sporulation. Fungi were isolated from barley seeds using potato dextrose agar (PDA) (Sigma, St. Louis, MO, USA) at $25^{\circ} \mathrm{C}$ for 7 days. Subsequently, growing colonies were selected based on their macroscopic characteristics, cut using a scalpel, and transferred to a new PDA plate for incubation under the same aforementioned conditions. Conidia and hyphae were maintained at $-84^{\circ} \mathrm{C}$ until analysis.

\section{Morphological characterization}

The morphological description of $C$. satious (Kumar et al., 2002; Manamgoda et al., 2014) and P. teres (Louw et al., 1995; Crous et al., 1995) was conducted as described. Growth rate and morphological descriptions (conidia and conidiophores) were performed using a PDA culture medium. A $0.5 \mathrm{~cm}$-diameter mycelium disk containing isolated conidia was placed in the center of each Petri dish. Fungi were grown at $25^{\circ} \mathrm{C}$ for one week or until they filled the entire Petri dish. Micrographs were taken with a scanning electron microscope (SEM) (JEOL, Model IT300, Boston, MA, USA).

\section{Molecular characterization}

The DNA of the strains identified as $C$. sativus and $P$. teres was obtained from mycelium grown in $250 \mathrm{ml}$ Erlenmeyer flasks containing $50 \mathrm{ml}$ of potato dextrose broth (PDB) (20\% potato, $15 \%$ dextrose $(\mathrm{w} / \mathrm{v}))$, using a modified method described by Aamir et al. (2015). Strains were grown with shaking $(220 \mathrm{rpm})$ at $25{ }^{\circ} \mathrm{C}$ for a week. Biomass was recovered and washed twice with TE buffer (10 mM Tris-HCl, 1 mM EDTA). DNA extraction of each isolate was performed according to Cuervo-Parra et al. (2011). The ITS regions (ITS1 and ITS2) of the ribosomal DNA (rDNA) gene were amplified by PCR using the primers ITS1 and ITS4 (Ramírez-Cariño et al., 2020).

The PCR system was the same as described by Cuervo-Parra et al. (2014). PCR reactions were placed in an automatic thermal cycler (Techne PRIME3, Series No. 31309, Cole Parmer, Staffordshire, UK) under the following conditions:
5 min initial denaturation at $95^{\circ} \mathrm{C}$, followed by 30 cycles of $1 \mathrm{~min}$ denaturation at $95^{\circ} \mathrm{C} ; 1 \mathrm{~min}$ primer annealing at $57^{\circ} \mathrm{C} ; 1 \mathrm{~min}$ extension at $72^{\circ}$; and a final extension period of $12 \mathrm{~min}$ at $72^{\circ} \mathrm{C}$. The resulting products were purified with the GeneClean ${ }^{\circledR}$ II kit (MP Biomedicals, Carlsbad, CA, USA) according to the manufacturer's protocol. Amplicons were observed on a $2 \%$ agarose gel stained with ethidium bromide. Sequence pair alignment was carried out using BLAST software (Zhang et al., 2000), and the DNA sequences of $C$. sativus and $P$. teres were aligned with other related sequences from GenBank (Andrie et al., 2008; Aggarwal et al., 2010a; Aggarwal et al., 2010b; Kleczewski, 2010; Liu and Friesen, 2010; Lartey et al., 2013; Moya et al., 2013; Manamgoda et al., 2014; Shim, 2014; Phillips et al., 2016) through ClustalW (Larkin et al., 2007) to identify variable regions or base sequences. Distance matrices were calculated between all pairs of sequences considered in the multiple alignment, and two phylogenetic trees were generated based on Neighbor-Joining (NJ) and Maximum Likelihood (ML) statistical methods using MEGA6 software (Tamura et al., 2013). Same as for the statistical analysis, the phylogenetic analysis was performed based on: bootstrap test of phylogeny using 1000 random bootstrap replications, nucleotide substitutions, Kimura's two-parameter model, uniform rates among sites and homogeneous pattern among lineages. Additionally, the following statistical parameters were used for the ML statistical method: ML Heuristic method, NearestNeighbor-Interchange (NNI) and branch swap filter, very strong. All parameters were calculated using MEGA6 software (Tamura et al., 2013).

\section{RESULTS AND DISCUSSION}

\section{Isolation of strains}

Sixty-nine fungal strains were isolated and morphologically characterized from five barley varieties (Esmeralda, Forrajera, Alina, Adabella, and Gaviota) (data not shown). Based on the morphological characterization and the importance of some of these fungi as pathogens, 16 strains were identified as $C$. sativus and $P$. teres (Table 1). It is observed that these fungi have been present in the field over several years. C. sativus strains have been present in Puebla and in all the municipalities of Hidalgo, showing a constant presence in barley plantations.

\section{Morphological characterization}

Colonies grown on PDA medium $\left(5-7 \mathrm{~d}, 25^{\circ} \mathrm{C}\right)$ showed a diameter of 36 to $42 \mathrm{~mm}$, with an initial whitish growth that later acquired a gray-brown 
Table 1. Fungal strains isolated from infected barley seeds.

\begin{tabular}{|c|c|c|c|c|c|}
\hline Specie & Strain & $\begin{array}{l}\text { Barley } \\
\text { sample }\end{array}$ & Variety & Sample origin & $\begin{array}{c}\text { Collection } \\
\text { year }\end{array}$ \\
\hline C. sativus & JCP3 & S1 & Esmeralda & Apan, Hidalgo & 2010 \\
\hline P. teres & JCP2 & & & & \\
\hline C. sativus & $\mathrm{JCP} 43$ & S2 & Forrajera & Apan, Hidalgo & 2011 \\
\hline C. sativus & JCP65 & S3 & Forrajera & Tepeapulco, Hidalgo & 2013 \\
\hline $\begin{array}{l}\text { C. satious } \\
P . \text { teres }\end{array}$ & $\begin{array}{l}\text { JCP14 } \\
\text { JCP16 }\end{array}$ & S4 & Alina & Mijapa, Hidalgo & 2012 \\
\hline C. satious & $\mathrm{JCP} 44$ & S5 & Alina & Anan Hidalo ${ }_{0}$ & 2014 \\
\hline P. teres & JCP57 & J & & Apan, 1нualgo & 2014 \\
\hline P. teres & $\mathrm{JCP} 10$ & S6 & Esmeralda & San Felipe, Hidalgo & 2009 \\
\hline C. sativus & $\mathrm{JCP} 12$ & & & & \\
\hline P. teres & JCP7 & S7 & Adabella & Calpulalpan, Tlaxcala & 2013 \\
\hline $\begin{array}{l}P . \text { teres } \\
\text { C. sativus }\end{array}$ & $\begin{array}{l}\text { JCP19 } \\
\text { JCP30 }\end{array}$ & S8 & Esmeralda & Chignahuapan, Puebla & 2008 \\
\hline P. teres & JCP51 & S9 & Gaviota & Libres, Puebla & 2008 \\
\hline $\begin{array}{l}\text { C. sativus } \\
P . \text { teres }\end{array}$ & $\begin{array}{l}\text { JCP6 } \\
\text { ICP50 }\end{array}$ & S10 & Adabella & Almoloya, Hidalgo & 2012 \\
\hline
\end{tabular}

to black color, with irregularly shaped mycelial structures of white color, velvety, with an irregular or wavy margin. Historically, the genus Cochliobolus has been characterized by having brown conidiophores and conidia that can be fusoid, straight, or curved, and germinating from a germinal tube at each end (Manamgoda et al., 2014). Abundant sporulation was observed after one week. The reverse was dark or black with concentric rings. The hyphae were gray to brown, smooth or verrucous. Asexual morphological characteristics on PDA medium showed abundant conidiophores, straight to flexuous, with septa, arising singly or grouped, simple or branched (Fig. 1A-C), with size of 130.59-154.53 × 6.18-7.76 $\mu \mathrm{m}$ (av. $=142.56 \mu \mathrm{m}, \mathrm{SD}=11.97, \mathrm{n}=32$, long; av. $=6.94 \mu \mathrm{m}, \mathrm{SD}=0.77, \mathrm{n}=32$, wide). Conidia were dark olivaceous brown to golden brown or slightly pale at ends, curved or straight, oval, cylindrical, fusiform or with broadly ellipsoidal shape, with rounded ends and a basal scar (Fig. 1D-G). A slight curvature was observed in some conidia. The size of the conidia was 77.78-146.4 $\times$ 15.66-19.64 $\mu \mathrm{m},($ av. $=112.09 \mu \mathrm{m}, \mathrm{SD}=34.31, \mathrm{n}=$ 32 , long; av. $=17.65 \mu \mathrm{m}, \mathrm{SD}=1.99, \mathrm{n}=32$, wide) with 3 to 10 pseudosepta. The conidial wall was smooth and distinctly thick in the pseudosepta. The morphological values obtained in the present study are within the range observed by other authors for other strains of $C$. sativus (Müller et al., 2005; Manamgoda et al., 2014). Therefore, based on the morphological characterization, the strains were identified as $C$. sativus (Kumar et al., 2002; Manamgoda et al., 2014; Romero et al., 2020).
Eight strains (JCP2, JCP7, JCP10, JCP16, JCP19, JCP50, JCP51 and JCP57) grown on PDA showed an initial hyaline growth that over time acquired an olivaceous brown to white-cream coloration, with cottony colonies with a $5.2 \mathrm{~mm}^{\text {day }}{ }^{-1}$ growth rate. The reverse showed a crenulated, dentate, serrate or an irregular growth with a coloration between yellow-creamy to light brown. The conidiophores observed on PDA medium showed different shapes, septate, being in the range of 3.64-79.48 $\times 10.56-16.82 \mu \mathrm{m}$ (av. $=41.56 \mu \mathrm{m}, \mathrm{SD}$ $=37.92, \mathrm{n}=32$; av. $=13.69 \mu \mathrm{m}, \mathrm{SD}=3.13, \mathrm{n}=32$ ). Conidia of isolates were 36.37-102.55 $\times 13.95$ $25.61 \mu \mathrm{m}$ (av. $=69.46 \mu \mathrm{m}, \mathrm{SD}=33.09, \mathrm{n}=32$; av. $=19.78 \mu \mathrm{m}, \mathrm{SD}=5.83, \mathrm{n}=32$ ), olivaceous brown, cylindrical, tapering to subtruncate bases, with transverse septa (dictyoseptate), constricted at the level of the septum (Fig. 2). The morphological results obtained for the strains of $P$. teres were in agreement with those previously reported in the literature (Crous et al., 1995; Louw et al., 1995; Romero et al., 2020). Although the teleomorph obtained in this study had minimum values for the conidiophores and conidia, the results agree with values reported by Crous et al. (1995) and Romero et al. (2020). Conidia are more important for the propagation of NB disease because they are generated throughout the growing season, meanwhile sexual reproduction can lead to the formation of new pathotypes (Statkeviciute et al., 2010).

\section{Molecular characterization}

The analysis of the ITS regions of rDNA is a simple and reproducible molecular tool 

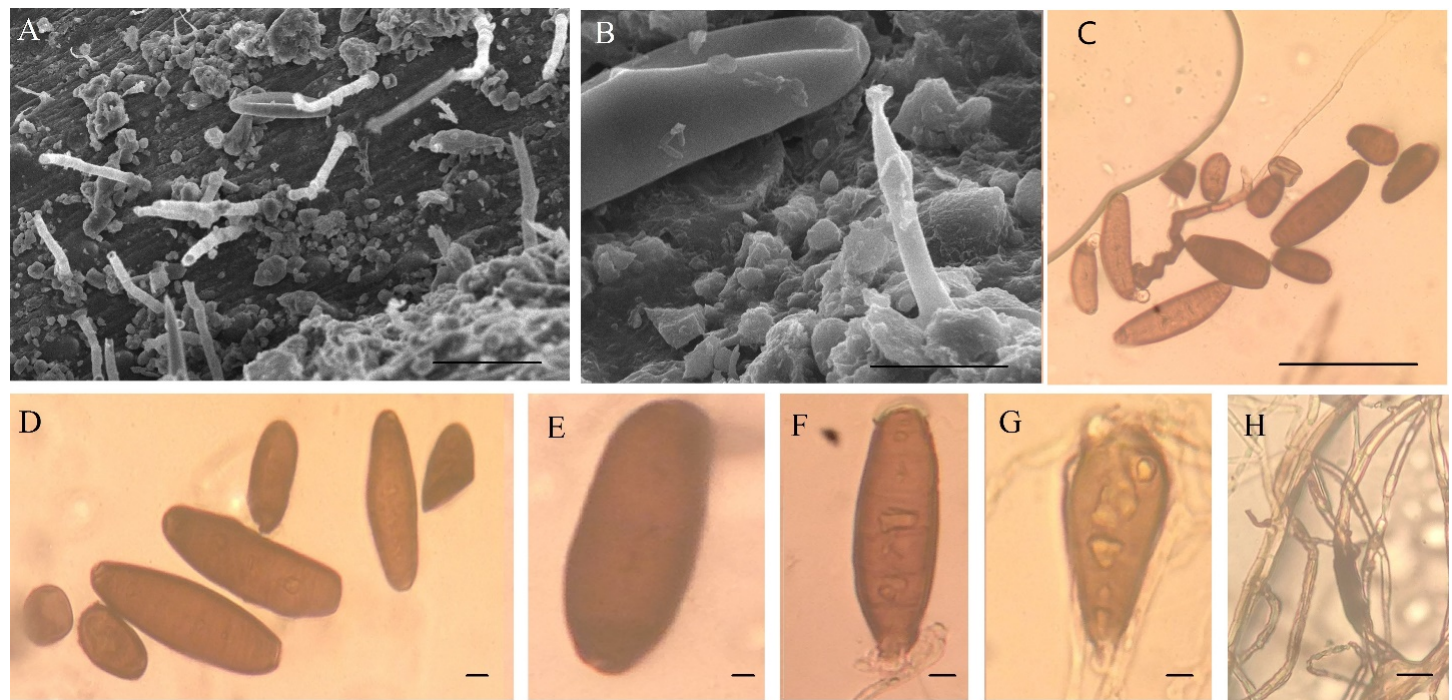

Fig. 1. Cochliobolus sativus colony on barley seeds. A and B: SEM of conidia and conidophore on the host, bar $=50 \mu \mathrm{m}$ and $10 \mu \mathrm{m}$, respectively. C: Optical microscopy of conidia and conidophore, bar $=50 \mu \mathrm{m}$. D to G: Conidia produced on PDA cultures, bar $=10 \mu \mathrm{m} . \mathrm{H}$ : Optical microscopy of conidiophores, bar $=10 \mu \mathrm{m}$.
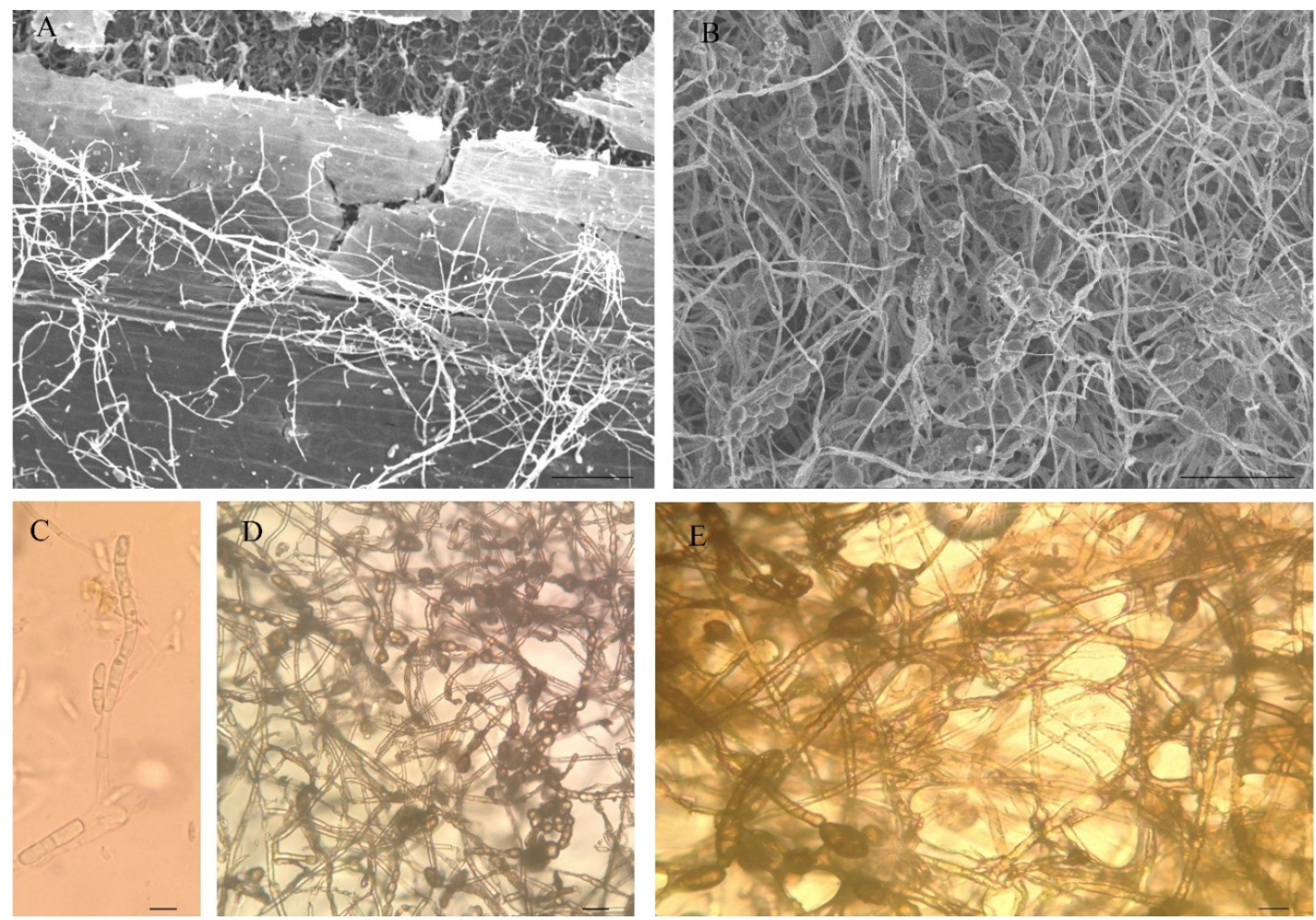

Fig. 2. SEM of $P$. teres conidiophores and conidia. A: Mycelium and conidiophores on barley leaves, bar $=100 \mu \mathrm{m}$. B: Mycelium and spherical mycelium structures on PDA growing medium, bar $=50 \mu \mathrm{m}$. C: Conidia dictyoseptate on broth PDB culture, bar $=5 \mu \mathrm{m}$. D and E: Muriform ascospores on PDA, bar $=10 \mu \mathrm{m}$. 
to identify and characterize fungal species (Mohammadi and Amini, 2015). A total of 16 new sequences of phytopathogenic fungi were generated in this study with additional sequences downloaded from GenBank. Phytopathogenic fungi of this study were identified using the ITS1 and ITS4 primers, by analyzing the DNA region containing the ITS1/5.8s/ITS2 sequence. The amplified regions of the isolated fungal strains had a size between 507 and $617 \mathrm{bp}$ and were deposited into the NCBI GenBank databases with the following accession numbers KX951412, KX066030, KX066031, KX066032, KX066033, KX066034, KX066035, KX066036 for C. sativus, and KX115407, KX115408, KX115409, KX115410, KX115411, KX115412, KX115413, KX115414 for $P$. teres.

From ITS regions, the data obtained for all the sequences of Cochliobolus and Pyrenophora were consistent with the results reported in previous studies for Pyrenophora graminea, P. teres, and $P$. teres f. maculate (Carlsen et al., 2017; Poudel et al., 2019) and for several species of Bipolaris (Manamgoda et al., 2014). The genetic differences observed between isolates of $C$. sativus and $P$. teres, collected from different cereal-growing regions in Mexico, could explain the difference in virulence (Christensen, 1926; Sultana et al., 2018). In this sense, a study that evaluated a barley core collection for SFNB reaction revealed distinct genotype-specific pathogen virulence and host susceptibility (Neupane et al., 2015). $\mathrm{Wu}$ et al. (2020) performed a PCR assay with the ToxA-specific marker, a significant virulence factor related to wheat spot blotch disease, for 196 Mexican strains of C. sativus isolated from wheat and barley, and reported the presence of ToxA in 20 of the isolates, but none of the eight B. sorokiniana isolated from barley was ToxApositive. Compared with reports for other geographical regions (McDonald et al., 2018; Friesen et al., 2018; Navathe et al., 2020), these results suggest that the Mexican populations of C. sativus are not carriers of ToxA.

Phylogenetic analysis of the Mexican barley sequences and other 64 related sequences from GenBank generated a tree by the NJ method (Fig. 3), and another tree by the ML method (Fig. 4). The trees were rooted with the GenBank sequences AB474001 and KM659218 of Bacillus subtilis as outgroup to infer phylogenetic relationships (El-Sayed et al., 2008; You and Zhang, 2014). In the present study, two distinctive fungal taxa isolated from barley seeds were $\geq 96 \%$ similar to Cochliobolus and Pyrenophora. Of the ITS regions, the ITS2 region was the most conserved for all strains of Cochliobolus and Pyrenophora. The optimal NJ tree with the sum of branch length
$=1.62618503$ and the ML tree with the Log Likelihood $=-1809.97$ are shown. The NJ and ML analyses showed that the DNA sequences of $P$. teres and $C$. sativus, lined up at separate branches, formed two major clusters (I and II). Cluster I contained the JCP50, JCP19, JCP16, JCP7, JCP57, JCP2, JCP51 and JCP10 strains, and related Pyrenophora/Drechslera isolates from GenBank. Cluster II contained the JCP12, JCP14, JCP65, JCP30, JCP3, JCP43, JCP6 and JCP44 strains, and related strains of Cochliobolus also from GenBank. Each node of the phylogenetic trees was well supported by high bootstrap values (Figs. 3 and $4)$.

At the top of the phylogenetic trees, it can be seen that the Mexican strains isolated from barley as $P$. teres were phylogenetically related to the NCBI GenBank sequences of $P$. teres from South Korea (Shim, 2014), Argentina (Moya et al., 2013), and United States of America (Liu and Friesen, 2010; Moya et al., 2013), and of P. teres f. teres (Liu and Friesen, 2010) and P. teres f. maculata, both from the United States of America (Lartey et al., 2013). There were some variations between the sequences of the strains of $P$. teres isolated from Mexican barley in terms of deletions, insertions, substitutions and base transversions during multiple sequence alignment using ClustalW software (Larkin et al., 2007). However, the differences do not represent enough variation within the NCBI GenBank Pyrenophora sequences as to indicate that the Mexican strains of $P$. teres are a different species.

The bootstrap value obtained for the strains of $P$. teres by the NJ method was 96 during the phylogenetic analysis, while values generated by the ML method were higher. Since values were high, these strains were easily distinguishable from other sequences of Pyrenophora species from GenBank grouped in other branches of the same Cluster I of the phylogenetic trees (e.g., Pyrenophora tetrarrhenae, Drechslera poae, and Pyrenophora tricini-repentis). Nevertheless, more gene region information is needed to establish genetic divergence from other species or continuity within the $P$. teres complex. In 1967, Pyrenophora japonica was considered as a mutant strain of $P$. teres, consisting of numerous clones that are tailored to environments (McDonald, 1967). Later studies have confirmed that $P$. japonica was not a separate species (Crous et al., 1995; Campbell et al., 1999). Other studies have described that $P$. graminea morphologically resembles $P$. teres but causes a leaf stripe disease in the barley plant, while it cannot infect leaves directly through conidia (Smedegard-Petersen, 1977; Liu et al., 2011). Furthermore, phylogenetic analyzes show that groups of $P$. graminea 


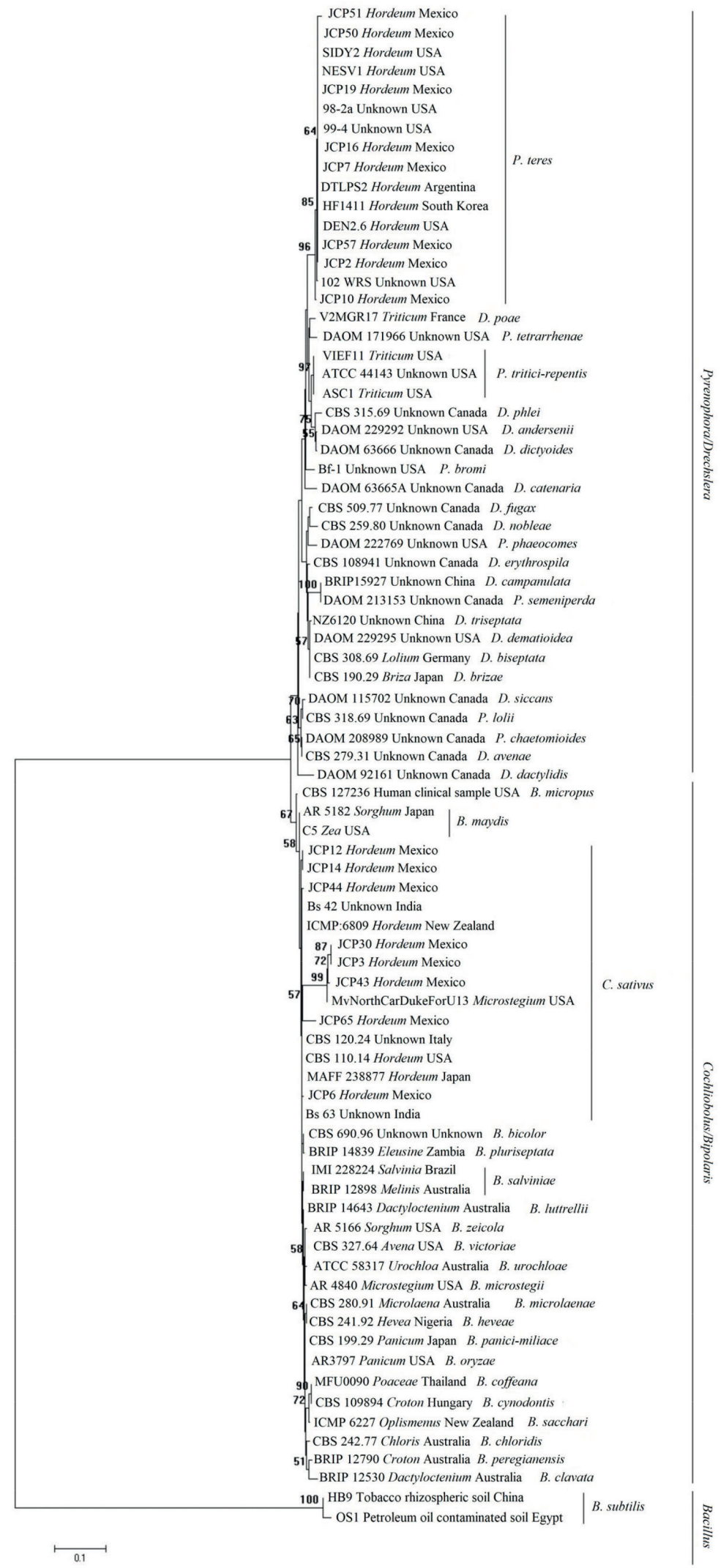

Fig. 3. Phylogenetic analysis generated for Cochliobolus and Pyrenophora from a neighbor-joining analysis based on the ITS alignment. The numbers in the nodes are the bootstrap values. 


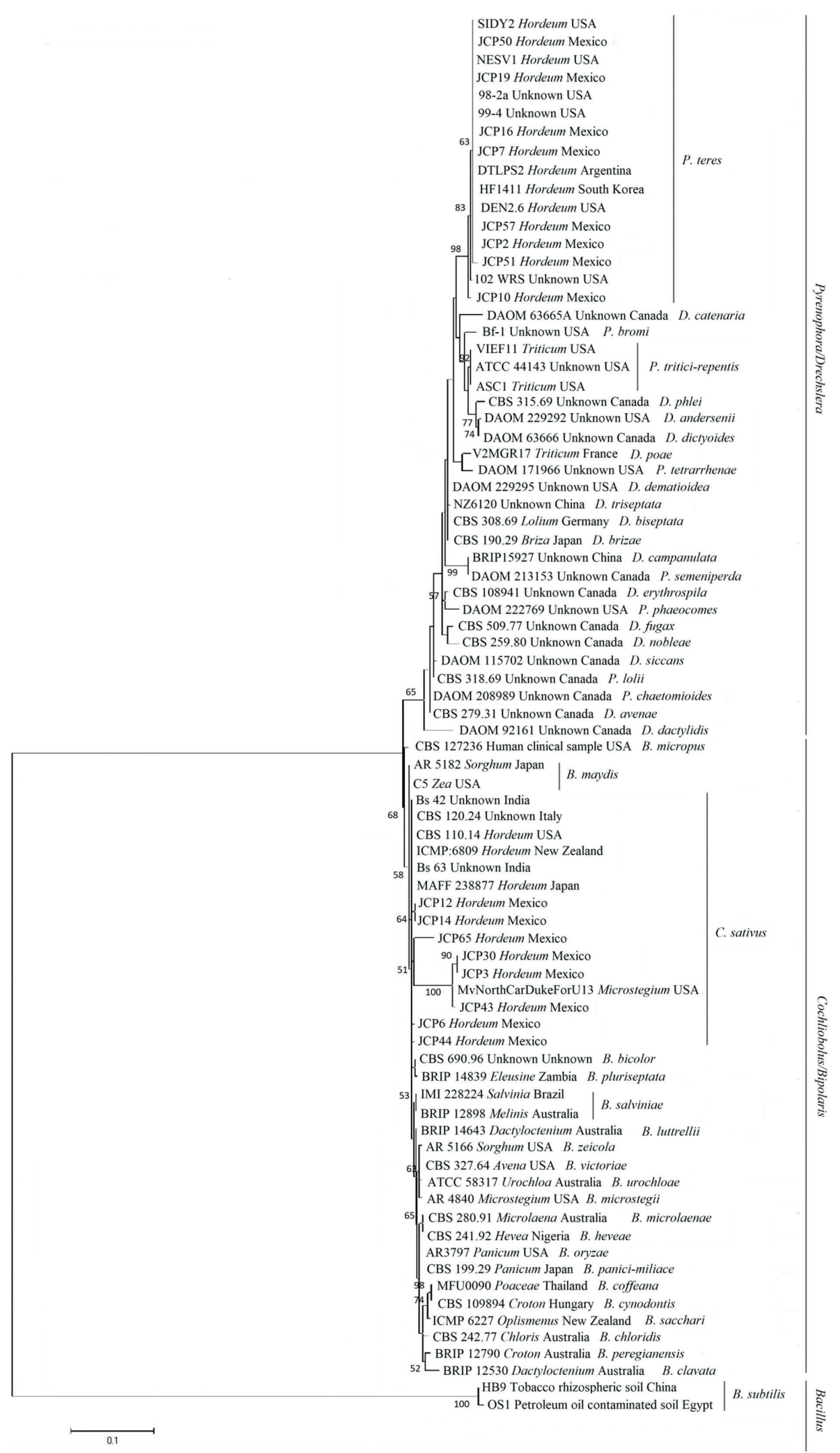

Fig. 4. Phylogenetic analysis generated for Cochliobolus and Pyrenophora from a Maximum Likelihood analysis based on the ITS alignment. The numbers in the nodes are the bootstrap values. 
sequences are the closest neighbors to groups of $P$. teres sequences, being more closely related to $P$. teres $\mathrm{f}$. maculata than to $P$. teres $\mathrm{f}$. teres (Bakonyi and Justesen, 2007; Rau et al., 2007).

In Australia and South Africa, the anamorph state of Pyrenophora hordei shows morphological characteristics similar to those of $P$. teres, but its teleomorph state is different in both morphology and disease symptoms in barley (Scott, 1994). Another study suggests that the sexual recombination between the two forms of $\mathrm{NB}$ of barley occurs naturally in the field, leading to the appearance of a new SFNB differential set (McLean et al., 2014). Furthermore, to improve the resolution of the phylogenetic tree, a second gene such as gpd could be incorporated to make the phylogenetic analysis more robust (Zhang and Berbee, 2001; Lepoint et al., 2010; Vasighzadeh et al., 2019). In addition, it would be useful to detect intraspecific variability in $P$. teres by using specific primers to detect and discriminate between net and spot forms (Williams et al., 2001; Svobodova et al., 2005; Leisova et al., 2006; Poudel et al., 2019).

The fungal sequences of the genus Cochliobolus isolated from barley grains were aligned in the upper part of Cluster II in the two phylogenetic trees, together with other $C$. sativus sequences from GenBank from several geographical regions (Figs. 3 and 4). For the NJ method, the JCP12, JCP14, and JCP44 strains were located near C. sativus sequences from India (Aggarwal et al., 2010a) and New Zealand (Phillips et al., 2016). For the ML method, these sequences were aligned in other branches of the same clade, along with the other C. sativus sequences isolated from Mexican barley. The JCP30, JCP3, and JCP43 strains lined up next to other strains of $C$. sativus isolated in the United States of America (Kleczewski, 2010), supported by a high bootstrap value for the NJ and ML methods (Figs. 3 and 4). Additionally, the JCP65 strain was aligned near two sequences of C. sativus isolated in Italy and the United States of America (Manamgoda et al., 2014), respectively, with a bootstrap support value of 57 for the NJ method. For the ML method, this sequence was aligned near the JCP30, JCP3, JCP43 strains isolated from barley samples in the present study and other strain of $C$. sativus isolated in the United States of America (Kleczewski, 2010). Finally, the JCP6 strain was aligned between two others $C$. sativus sequences isolated in India (Aggarwal et al., 2010b) and Japan (Manamgoda et al., 2014) by the NJ method. Furthermore, the phylogenetic analysis conducted by the ML method allowed differentiating the $C$. sativus sequences isolated from barley in Mexico from the GenBank database from other geographical regions (Fig. 4).

Although the bootstrap values for the $C$. satious sequences in the two phylogenetic trees were not very high (67 and 68 for the NJ and ML methods, respectively), it was possible to clearly differentiate the isolates from the other sequences belonging to other species within the genus Cochliobolus. In addition, the genetic variation of C. sativus strains isolated from barley seeds from different cereal-growing regions in Mexico is consistent with what reported in the literature (Duveiller and Altamirano, 2000; Kumar et al., 2002; Bashyal et al., 2011; Manamgoda et al., 2012; Manamgoda et al., 2014).

The obtained molecular results are in agreement with previous studies (Manamgoda et al., 2012; Manamgoda et al., 2014). The large number of fungal strains considered in various studies conducted worldwide shows that $C$. sativus derives from a continuous isolation with variations in virulence and aggressiveness with specific and non-specific interactions (Maraite et al., 1998; Ghazvini and Tekauz, 2007). On the other hand, the distinction of the genus Cochliobolus from its sister group observed in the phylogenetic analysis generated for Cochliobolus and Pyrenophora sequences by the NJ and ML methods (based on the ITS alignment), agrees with molecular data available in the literature (Berbee et al., 1999), then redefined by using phylogenetic analyses of ITS, GPDH, TEF, and LSU sequences (Manamgoda et al., 2012).

\section{CONCLUSIONS}

The fungi $P$. teres and $C$. sativus that cause spot blotch disease of barley and the pathogenesis involving these fungi were subjected to detailed studies at the molecular level. Morphological and ITS sequence-based identification showed that the fungal strains isolated from barley grown in the highlands of Mexico were between 96 and $99 \%$ similar to C. sativus and P. teres. Strains of C. sativus can be identified with high precision using BLAST software for ITS sequences against the sequences deposited in the NCBI database. However, this is not the case for $P$. teres as the genus can be determined but not the intragenic species. The data obtained in this study will allow for the subsequent development of biological control strategies for these pathogens with other fungal agents, such as Trichoderma spp.

\section{ACKNOWLEDGMENTS}

This research was funded by PRODEP (Programa para el Desarrollo Profesional Docente) through the project PROMEP-PTC-553, Pachuca, Hidalgo, Mexico. We also appreciate the support of María Pamela Cortes De la Fuente, 
from Chilean Journal of Agricultural \& Animal Sciences for her help checking and improve the English language of the final manuscript.

\section{LITERATURE CITED}

Aamir, S., S. Sutar, S.K. Singh, and A. Baghela. 2015. A rapid efficient method of fungal genomic DNA extraction, suitable for PCR based molecular methods. Plant Pathol. Quar. J. Fungal Biolog. 5:74-81. doi:10.5943/ ppq/5/2/6

Aggarwal, R., S. Sharma, S. Gupta, and S. Banerjee. 2010a. Bipolaris sorokiniana. Available at http:// www.ncbi.nlm.nih.gov/nuccore/hm195252. (Accessed 6 Sep. 2020).

Aggarwal, R., S. Sharma, S. Gupta, and S. Banerjee. 2010b. Bipolaris sorokiniana. Available at http://www.ncbi.nlm.nih.gov/ nuccore/hm195254. (Accessed 6 Sep. 2020).

Al-Sadi, A.M. 2021. Bipolaris sorokiniana-Induced black point, common root rot, and spot blotch diseases of wheat: A review. Front. Cell. Infect. Microbiol. 11:1-9. doi:10.3389/ fcimb.2021.584899

Al-Sadi, A.M., and M.L. Deadman. 2010. Influence of seed-borne Cochliobolus sativus (anamorph Bipolaris sorokiniana) on crown rot and root rot of barley and wheat. J. Phytopathol. 158:683690. doi:10.1111/j.1439-0434.2010.01684.x

Andrie, R.M., C.L. Schoch, R. Hedges, J.W. Spatafora, and L.M. Ciuffetti. 2008. Homologs of ToxB, a host-selective toxin gene from Pyrenophora tritici-repentis, are present in the genome of sister-species Pyrenophora bromi and other members of the Ascomycota. Fungal Genet. Biol. 45:363-377. doi:10.1016/j. fgb.2007.10.014

Bakonyi, J., and A.F. Justesen. 2007. Genetic relationship of Pyrenophora graminea, $P$. teres f. maculata and $P$. teres $f$. teres assessed by RAPD analysis. J. Phytopathol. 155(2):76-83. doi:10.1111/j.1439-0434.2007.01192.x

Bashyal, B.M., R. Chand, C. Kushwaha, A.K. Joshi, and S. Kumar. 2011. Bipolaris sorokiniana of barley: infection behaviour in different members of Poaceae. Indian Phytopathol. 64:28-31

Berbee, M.L., M. Pirseyedi, and S. Hubbard. 1999. Cochliobolus phylogenetics and the origin of known, highly virulent pathogens, inferred from ITS and glyceraldehyde-3-phosphate dehydrogenase gene sequences. Mycologia 91:964-977. doi:10.1080/00275514.1999.12061 106.
Campbell, G.F., P.W. Crous, and J.A. Lucas. 1999. Pyrenophora teres f. maculata, the cause of Pyrenophora leaf spot of barley in South Africa. Mycol. Res. 103(3):257-267. doi:10.1017/S0953756298007114

Carlsen, S.A., A. Neupane, N.A. Wyatt, J.K. Richards, J.D. Faris, S.S. Xu, et al. 2017. Characterizing the Pyrenophora teres $\mathrm{f}$. maculata-Barley Interaction Using Pathogen Genetics. G3-Genes Genom. Genet. 7:26152626. doi:10.1534/g3.117.043265

Carmona, M., y F. Sautua. 2015. Manual práctico para el diagnóstico de enfermedades foliares y su control con fungicidas en los cultivos de trigo y cebada. Facultad de Agronomía, Universidad de Buenos Aires, Buenos Aires, Argentina.

Carmona, M., y F. Sautua. 2017. Criterios para el manejo integrado de las enfermedades. $p$. 93-108. En Divito, A.G., y O.F. García (ed.) Manual del cultivo de trigo. 1er ed. Instituto Internacional de Nutrición de Plantas. Argentina.

Carretero, R., A.R. Serrano, y G. Guarino. 2015. Claves para un correcto monitoreo y control de enfermedades de trigo y cebada. Cultivar Decisiones Conocimiento Agropecuario. 95:1-6. Disponible en http://www. cultivaragro.com.ar/capacitaciones/95_ EnfermedadesTrigo_1443621944.pdf. (Consulta 20 mayo 2020).

Christensen, J.J. 1926. Physiological specialization and parasitism of Helminthosporium sativum. Technical Bulletin. University of Minnesota, USA.

Couretot, L., L. Parisi, M. Fernández, G. Magnone, H. Rusian, y A. Samoiloff. 2017. Sanidad de semillas en trigo y cebada. Importancia del tratamiento de semillas. Fitopatología 10:30-33.

Crous, P.W., B.J.H. Janse, J. Tunbringe, and G. Holz. 1995. DNA homology between Pyrenophora japonica and P. teres. Mycol. Res. 99:1098-1102. doi:10.1016/S09537562(09)80778-8

Cuervo-Parra, J.A., V. Sanchez-Lopez, M. Ramírez-Suero, and M. Ramírez-Lepe. 2011. Morphological and molecular characterization of Moniliophthora roreri causal agent of frosty pod rot of cocoa tree in Tabasco, Mexico. Plant Pathol. J. 10:122-127. doi:10.3923/ppj.2011.122.127

Cuervo-Parra, J.A., V. Sánchez-López, T. Romero-Cortes, and M. Ramírez-Lepe. 2014. Hypocrea/Trichoderma viridescens ITV43 with potential for biocontrol of Moniliophthora roreri Cif \& Par, Phytophthora megasperma and Phytophthora capsici. Afr. J. Microbiol. Res. 8:1704-1712. doi:10.5897/AJMR2013.6279 
Dumalasová, V., L. Svobodová, and A. Hanzalová. 2012. Differentially expressed gene transcripts in wheat and barley leaves upon leaf spot infection. Czech J. Genet. Plant Breed. 48:108119. doi:10.17221/187/2011-CJGPB

Duveiller, E., and G. Altamirano. 2000. Pathogenicity of Bipolaris sorokiniana isolates from wheat roots, leaves and grains in Mexico. Plant Pathol. 19:235-242. doi:10.1046/ j.1365-3059.2000.00443.x

El-Sayed, W.S., M.A. Ibrahim, and F.M. El-Beih. 2008. Biodegradation of chlorophenols from industrial wastes in different sites of Egypt by some locally isolated bacteria. Available at http://www.ncbi.nlm.nih.gov/nuccore/ ab474001. (Accessed 8 Sep. 2020).

Ellwood, S.R., V. Piscetek, W.J. Mair, J.A., Lawrence, F.J. Lopez-Ruiz, and C. Rawlinson. 2018. Genetic variation of Pyrenophora teres f. teres isolates in Western Australia and emergence of a Cyp51A fungicide resistance mutation. Plant. Pathol. 68(1):135-142. doi:10.1111/ppa.12924

FAO. 2020. Situación Alimentaria Mundial. Nota informativa de la FAO sobre la oferta y la demanda de cereales. Organización de las Naciones Unidas para la Alimentación y la Agricultura. Disponible en http:// www.fao.org/worldfoodsituation/csdb/ es/\#: : text $=$ De $\% 20$ acuerdo $\% 20$ con $\% 20$ los\%20pron\%C3\%B3sticos, del\%20nivel\%20 de $\% 202019 \% 2 \mathrm{~F} 20$.(Consultado 13 enero 2021).

Friesen, T.L., D.J. Holmes, R.L. Bowden, and J.D. Faris. 2018. ToxA is present in the U.S. Bipolaris sorokiniana population and is a significant virulence factor on wheat harboring Tsn1. Plant Disease 102:2446-2452. doi:10.1094/PDIS-03-18-0521-RE

Forcelini, C.A. 1991. Importância epidemiológica de fungos do gênero Helminthosporium em sementes de trigo e cevada. p. 179-219. In Menten, J.O.M. (ed.) Patógenos em sementes detecção, Danos e Controle Químico. 1st ed. Piracicaba, Brazil, Luiz of Queiróz School of Agriculture, Brazil.

Ghazvini, H., and A. Tekauz. 2007. Virulence diversity in the population of Bipolaris sorokiniana. Plant Dis. 91:814-821. doi:10.1094/ PDIS-91-7-0814

Jones, D.G., D. Gareth, and B.C. Clifford. 1983. Cereal diseases: their pathology and control. 2nd ed. John Wiley and Sons, Chichester, UK.

Kleczewski, N.M. 2010. Pathogenic Bipolaris spp. isolated from Microstegium vimineum and native grasses in the Eastern United States. Available at http://www.ncbi.nlm.nih.gov/ nuccore/hm998314. (Accessed 4 Oct 2020).
Kumar, S., N. Kumar, S. Prajapati, and S. Maurya. 2020. Review on spot blotch of wheat: An emerging threat to wheat basket in changing climate. J. Pharmacogn. Phytochem. 9(2):1985-1997.

Kumar, J., P. Schäfer, R. Hückelhoven, G. Langen, H. Baltruschat, E. Stein, et al. 2002. Bipolaris sorokiniana, a cereal pathogen of global concern: cytological and molecular approaches towards better control. Mol. Plant Pathol. 3:185-195. doi:10.1046/j.13643703.2002.00120.x

Larkin, M.A., G. Blackshields, N.P. Brown, R. Chenna, P.A. McGettigan, H. McWilliam, et al. 2007. ClustalW and Clustal X version 2.0. Bioinformatics 23:2947-2948. doi:10.1093/ bioinformatics/btm 404

Lartey, R.T., T.C. Caesar-Tonthat, A.J. Caesar, U.M. Sainju, and R.G. Evans. 2013. First report of Spot Form Net Blotch caused by Pyrenophora teres $\mathrm{f}$. maculata on barley in the Mon-Dak Area of the United States. Plant Dis. 97:143-144. doi:10.1094/PDIS-07-120657-PDN

Leisova, L., V. Minarikova, L. Kucera, and J. Ovesna. 2006. Quantification of Pyrenophora teres in infected barley leaves using real-time PCR. J. Microbiol. Methods 67(3):446-455. doi:10.1016/j.mimet.2006.04.018

Lepoint, P., M.-E. Renard, A. Legrève, E. Duveiller, and H. Maraite. 2010. Genetic diversity of the mating type and toxic production genes in Pyrenophora tritici-repentis. Phytopathology 100:474-483. doi:10.1094/PHYTO-100-5-0474

Liu, Z.H., and T.L. Friesen. 2010. Identification of Pyrenophora teres f. maculata, causal agent of Spot Type Net Blotch of barley in North Dakota. Plant Dis. 94:480. doi:10.1094/PDIS94-4-0480A

Liu, Z.H., S.R. Ellwood, R.P. Oliver, and T.L. Friesen. 2011. Pyrenophora teres: profile of an increasingly damaging barley pathogen. Mol. Plant Pathol. 12(1):1-19. doi: 10.1111/j.13643703.2010.00649.x

Louw, J.P.J., D. Victor, P.W. Crous, G. Holz, and B.J.H. Janse. 1995. Characterization of Pyrenophora isolates associated with spot and net type lesions on barley in South Africa. J. Phytopathol. 143:129-134. doi:10.1111/j.1439-0434.1995.tb00245.x

Manamgoda, D.S., L. Cai, E.H.C. McKenzie, P.W. Crous, H. Madrid, E. Chukeatirote, et al. 2012. A phylogenetic and taxonomic re-evaluation of the Bipolaris - Cochliobolus Curoularia Complex. Fungal Divers. 56:131144. doi:10.1007/s13225-012-0189-2 
Manamgoda, D.S., A.Y. Rossman, L.A. Castlebury, P.W. Crous, H. Madrid, E. Chukeatirote, et al. 2014. The genus Bipolaris. Stud. Mycol. 79:221-288. doi:10.1016/j.simyco.2014.10.002

Maraite, H., V. Daumerie, T. Di Zinno, H. Longrée, and E. Duveiller. 1998. Fungi associated with foliar blight of wheat in warmer areas. p. 293-300. In Duveiller, E., H.J. Dubin, J. Reeves, and A. McNab (eds.) Proceedings of the International Workshop on Helminthosporium Diseases of Wheat: Spot Blotch and Tan Spot. 1st ed. CIMMYT, Mexico.

Marshall, J.M., K. Kinzer, and R.S. Brueggeman. 2015. First report of Pyrenophora teres f. maculata the cause of spot form net blotch of barley in Idaho. Plant Dis. 99:1860. doi:10.1094/PDIS-03-15-0349-PDN

Mata-Santoyo, C.I., S.G. Leyva-Mir, M. CamachoTapia, J.M. Tovar-Pedraza, J. Huerta-Espino, H.E. Villaseñor-Mir, et al. 2018. Agresividad de aislados de Bipolaris sorokiniana y Alternaria alternata en variedades de trigo en México. Rev. Mex. Fitopatol. 36:432-443. doi:10.18781/r.mex.fit.1803-3

McDonald, W.C. 1967. Variability and the inheritance of morphological mutants in Pyrenophora teres. Phytopathology 57:747755.

McDonald, M.C., D. Ahren, S. Simpfendorfer, A. Milgate, and P.S. Solomon. 2018. The discovery of the virulence gene ToxA in the wheat and barley pathogen Bipolaris sorokiniana. Mol. Plant Pathol. 19:432-439 doi:10.1111/mpp.12535.

McLean, M.S., A. Martin, S. Gupta, M.W. Sutherland, G.J. Hollaway, and G.J. Platz. 2014. Validation of a new spot form of net blotch differential set and evidence for hybridization between the spot and net forms of net blotch in Australia. Australas. Plant Path. 43:223-233. doi:10.1007/s13313014-0285-8.

McLean, M.S., and G.J. Hollaway. 2018. Control of net form of net blotch in barley from seedand foliar-applied fungicides. Crop Pasture Sci. 70(1):55-60. doi:10.1071/CP18142.

Medd, R.W., G.M. Murray, and D.I. Pickering. 2003. Review of the epidemiology and economic importance of Pyrenophora semeniperda. Australas. Plant Path. 32:539550. doi:10.1071/AP03059

Mohammadi, A., and Y. Amini. 2015. Molecular characterization and identification of Acrostalagmus luteoalbus from Saffron in Iran. Agric. Sci. Dev. 4:16-18.
Moya, P., M.N. Sisterna, and P.A. Balatti. 2013. Morpho-cultural characteristics and ribosomal sequences of Drechslera teres, the etiological agent of net blotch in barley. Available at http://www.ncbi.nlm.nih.gov/ nuccore/kf656729 (Accessed 9 Sep. 2020).

Müller, M.V.G., J.C. Germani, and S.S.T. Van Der. 2005. The use of RAPD to characterize Bipolaris sorokiniana isolates. Genet. Mol. Res. 4:642-652.

Murray, T.D., T.D. Parry, and N.D. Cattlin. 2009. Diseases of small grain cereal crops, a color handbook. 2nd ed. Manson Publishing, London, UK.

Musaed, E., R. Chand, and A.K. Joshi. 2013. Biochemical and histochemical parameters associated with slow blighting of spot blotch (Bipolaris sorokiniana (Sacc.) Shoem.) in wheat (Triticum spp.). Zemdirbyste100:191-198. doi:10.13080/z-a.2013.100.025

Navathe, S., P.S. Yadav, R. Chand, V.K. Mishra, N.K. Vasistha, P.K. Meher, et al. 2020. ToxA$T s n 1$ interaction for spot blotch susceptibility in Indian wheat: an example of inverse genefor-gene relationship. Plant Dis. 104:71-81. doi:10.1094/PDIS-05-19-1066-RE

Neupane, A., P. Tamang, R.S. Brueggeman, and T.L. Friesen. 2015. Evaluation of a barley core collection for Spot Form Net Blotch Reaction reveals distinct genotype-specific pathogen virulence and host susceptibility. Phytopathology 105:509-517. doi:10.1094/ PHYTO-04-14-0107-R

Pautasso, M., T. Döring, M. Garbelotto, L. Pellis, and M. Jeger. 2012. Impacts of climate change on plant diseases-opinions and trends. Eur. J. Plant Pathol. 133:1-19. doi:10.1007/s10658012-9936-1

Phillips, R., G. Grelet, A. McMillan, B. Song, B. Weir, T. Palmada, et al. 2016. Fungal denitrification: Bipolaris sorokiniana exclusively denitrifies inorganic nitrogen in the presence and absence of oxygen. FEMS Microbiol. Lett. 363(4):1-5. doi:10.1093/ femsle/fnw007

Poudel, B., M.S. McLean, G.J. Platz, J.A. Mcllroy, N.W. Sutherland, and A. Martin. 2019. Investigating hybridization between the forms of Pyrenophora teres based on Australian barley field experiments and cultural collections. Eur. J. Plant Pathol. 153(2):465473. doi:10.1007/s10658-018-1574-9

Producción Agrícola Mundial. 2020. Producción Mundial de Cebada 2020/2021. Disponible en http://www.produccionagricolamundial. com/cultivos/cebada.aspx. (Consultado 12 enero 2021). 
Ramírez-Cariño, H.F., P.C. GuadarramaMendoza, V. Sánchez-López, J.A. CuervoParra, T. Ramírez-Reyes, C.A. Dunlap, et al. 2020. Biocontrol of Alternaria alternata and Fusarium oxysporum by Trichoderma asperelloides and Bacillus paralicheniformis in tomato plants. Antonie van Leeuwenhoek 113(9):1247-1261. doi:10.1007/s10482-02001433-2.

Rau, D., G. Attene, A.H.D. Brown, L. Nanni, F.J. Maier, V. Balmas, et al. 2007. Phylogeny and evolution of mating-type genes from Pyrenophora teres, the causal agent of barley 'net blotch' disease. Curr. Genet. 51(6):377392. doi:10.1007/s00294-007-0126-1

Rehman, S., S. Gyawali, A. Amri, and R.P.S. Verma. 2020. First report of spot blotch of barley caused by Cochliobolus satious in Morocco. Plant Dis. 114:988-988. doi:10.1094/ PDIS-09-19-1923-PDN

Romero-Cortes, T., E.V.H. Pérez, P.P.A. López, G.C. Rodríguez-Jimenes, V.J. Robles-Olvera, B.J.E. Aparicio, et al. 2019. Antifungal activity of vanilla juice and vanillin against Alternaria alternata. CYTA J. Food. 17:375-383. doi:10.10 80/19476337.2019.1586776

Romero, C.T., E.V.H. Pérez, P.P.A. López, C.E. Rangel, O.M.A. Morales, M. Ramírez-Lepe, et al. 2020. Morphological characterization of phytopathogenic fungi isolated from seeds of barley plants (Hordeum vulgare) in Mexico. p. 275-288. In Ratikanta M., R.H. González, K.Ch. Aruna, D. Mandal, and S.N. Chandra (eds.) Sustainable Bioresource Management: Climate Change Mitigation and Natural Resource Conservation. 1st ed. Apple Academic Press, Inc., CRC Press (Taylor \& Francis). USA.

Savary, S., A. Nelson, A.H. Sparks, L. Willocquet, E. Duveiller, G. Mahuku, et al. 2011. International agricultural researchtackling the effects of global and climate changes on plantdiseases in the developing world. Plant Dis.95(10):1204-1216. doi:10.1094/PDIS-0411-0316

Scott, D.B. 1994. Drechslera spp. and their teleomorphs on small-grain cereals in South Africa. p. 194. National Research Council of Canada (ed.). Abstract of the Fifth International Mycological Congress, Vancouver, Canada.

Shim, H.K. 2014. Pyrenophora teres. Available at http://www.ncbi.nlm.nih.gov/nuccore/ kp097728. (Accessed 8 Oct 2020).

Sivanesan, A. 1990. CMI descriptions sheets: Set 99. Mycopathologia 109:41-62.doi:10.1007/ BF00437005
Smedegard-Petersen, V. 1977. Isolation of two toxins produced by Pyrenophora teres and their significance in disease development of netspot blotch of barley. Physiol. Plant Pathol. 10:203-208. doi:10.1016/0048-4059(77)90024-8

Statkeviciute, G., G. Brazauskas, R. Semaskiene, A. Leistrumaite, and Z. Dabkevicius. 2010. Pyrenophora teres genetic diversity as detected by ISSR analysis. Zemdirbyste 97(4):91-98.

Steffenson, B.J., and R.K. Webster. 1992. Pathotype diversity of Pyrenophora teres f. teres on barley. Phytopathology 82(2):170-177.

Sultana, S., S.K. Adhikary, M.M. Islam, and S.M.M. Rahman. 2018. Evaluation of pathogenic variability based on leaf blotch disease development components of Bipolaris sorokiniana in Triticum aestivum and agroclimatic origin. Plant Pathol. J. 34(2):93103. doi:10.5423/PPJ.OA.08.2017.0175

Svobodova, L., L. Kucera, V. Minarikova, and J. Ovesna. 2005. AFLP-based PCR markers that differentiate spot and net forms of Pyrenophora teres. Plant Pathol. 54(1):66-73. doi:10.1111/j.1365-3059.2005.01117.x

Tamura, K., G. Stecher, D. Peterson, A. Filipski, and S. Kumar. 2013. MEGA6: Molecular evolutionary genetics analysis version 6.0. Mol. Biol. Evol. 30:2725-2729. doi:10.1093/ molbev/mst197

Vasighzadeh, A., B. Sharifnabi, M. Javan-Nikkhah, and E.H. Stukenbrock. 2019. Pyrenophora lolii, a new species for the mycobiota. Mycol. Iran. 6(2):113-118. doi:10.22043/mi.2020.121823

Williams, K.J., C. Smyl, A. Lichon, K.Y. Wong, and H. Wallwork. 2001. Development and use of an assay based on the polymerase chain reaction that differentiates the pathogens causing spot form and net form of net blotch of barley. Australas. Plant Path. 30:37-44. doi:10.1071/AP00063

Wu, L., X. He, N. Lozano, X. Zhang, and P.K. Singh. 2020. ToxA, a significant virulence factor involved in wheat spot blotch disease, exists in the Mexican population of Bipolaris sorokiniana. Trop. Plant Pathol. doi:10.1007/ s40858-020-00391-4

You, C., and C. Zhang. 2014. Culturable bacteria isolated from tobacco rhizospheric soil. Available at http://www.ncbi.nlm.nih.gov/ nuccore/km6592182014. (Accessed 8 Sep 2020).

Zhang, G., and M.L. Berbee. 2001. Pyrenophora Phylogenetics Inferred from ITS and Glyceradehyde-3-Phosphate Dehydrogenase Gene Sequences. Mycologia 93:1048-1063. do i:10.1080/00275514.2001.12063240

Zhang, Z., S. Schwartz, L. Wagner, and W. Miller. 2000. A greedy algorithm for aligning DNA sequences. J. Comput. Biol. 7:203-214. doi:10.1089/10665270050081478 